\title{
Reproduction and Mortality of the High Arctic Wolf, Canis lupus arctos, in Northeast Greenland, 1978-1998
}

\author{
Ulf MARQuARD-PETERSEN
}

Greenland Wolf Research Project, 5836 E. 10 ${ }^{\text {th }}$ Circle, Anchorage, Alaska 99504 USA

Marquard-Petersen, U. 2008. Reproduction and mortality of the High Arctic Wolf, Canis lupus arctos, in northeast Greenland, 1978-1998. Canadian Field-Naturalist 122(2): 142-152.

Reproduction and mortality of the High Arctic Wolf (Canis lupus arctos) in northeast Greenland were investigated through a temporal and spatial analysis of data on litter sizes from direct counts of pups during 21 years (1978-1998). A minimum of 22 pups were produced in a total of six areas. Overall mean litter size was 2.0 pups/litter. This was the lowest mean litter size recorded for Wolves in North America through observations of pups in summer and was probably related to low availability and vulnerability of ungulate prey. Pack size and litter size were very strongly positively correlated. Large packs (4-7 adults) produced significantly more pups than smaller packs. Mean maximum litter size from 17 North American studies employing similar methods, suggested that maximum productivity of wolves in Greenland was $58 \%$ below that of wolves elsewhere. The number of Wolf pups born in North America was negatively correlated with increasing latitude. Eight mortalities were identified and were predominantly caused by humans despite the fact that this Wolf population inhabits a national park with year-round protection.

Key Words: Arctic Wolf, Canis lupus arctos, litter size, pup production, mortality, northeast Greenland.

Little information has been published on productivity and mortality of Wolves (Canis lupus arctos) in the High Arctic. Most reports have consisted of incidental sightings of Wolf pups on the Canadian Arctic Archipelago during fieldwork by researchers in a variety of fields (Soper 1928; Grace 1976; Miller and Russell 1977; Miller 1978; Gray 1983; Gray 1993). Three notable exceptions have included a systematic, 10-year study of behavioral ecology and productivity of a Wolf pack on Ellesmere Island (Mech 1995), an analysis of sightings of wolves throughout the Canadian Arctic Archipelago, including sightings of 16 litters (Miller and Reintjes 1995), and a four-year study of Wolves on central Baffin Island (Clark 1971*). These efforts suggested that productivity of Wolves on the Canadian Arctic Islands was lower than that of Wolves in subarctic ecosystems, and that pups were not produced during some years. Recent information on the causes of mortality of Wolves in the Canadian High Arctic has been lacking, but some information was published on human-caused mortality at a weather station and a settlement on Ellesmere Island (Riewe 1975, 1977; Grace 1976). Little is known about reproduction and mortality of Wolves in Greenland. Brief reports of incidental sightings of Wolf pups have been published, but no comprehensive, quantitative analysis has been conducted on litter sizes and frequencies of reproduction, primarily because insufficient and fragmentary material was available. Causes of mortality of Greenland Wolves have not been documented. About $94 \%$ of Wolf range is located inside the boundaries of the Northeast Greenland National Park (Figure 1), where Wolves receive year-round protection from hunting. Humancaused mortality was therefore not likely to be an important factor inside the park but could be important outside its boundaries due to opportunistic hunting by people from the Inuit settlement of Ittoqqortoormiit.

Objectives of this study were to (1) fill in gaps in knowledge by analyzing spatial and temporal attributes of known reproduction and mortality of Greenland Wolves and (2) to compare this information with trends in pup production across latitudes in North America. An analysis of sightings of Wolf pups in Greenland during 21 years (1978-1998) could reveal useful information pertaining to litter sizes and frequencies of reproduction. I also postulated that humancaused mortality would not constitute a substantial ratio of known mortality, because the majority of the Wolf population was protected inside the national park and because the permanent human population inside the park consisted of only approximately 27 persons, all of whom were geographically concentrated at a weather station and three year-round military outposts.

\section{Methods \\ Reproduction}

Four methods were employed to gather data on productivity of Wolves in northeast Greenland. First, I conducted specialized Wolf surveys lasting between two weeks and two months during May through August for eight consecutive years (1991-1998) for a total of 244 days in the field. Surveys were conducted in areas of northeast Greenland where coincidental sightings of Wolf pups had been made by members of expeditions during previous years. Dens were located during July. Two active dens were monitored, until an accurate litter count was obtained (Marquard-Petersen 1994). Second, $>100$ persons who had first-hand knowledge 


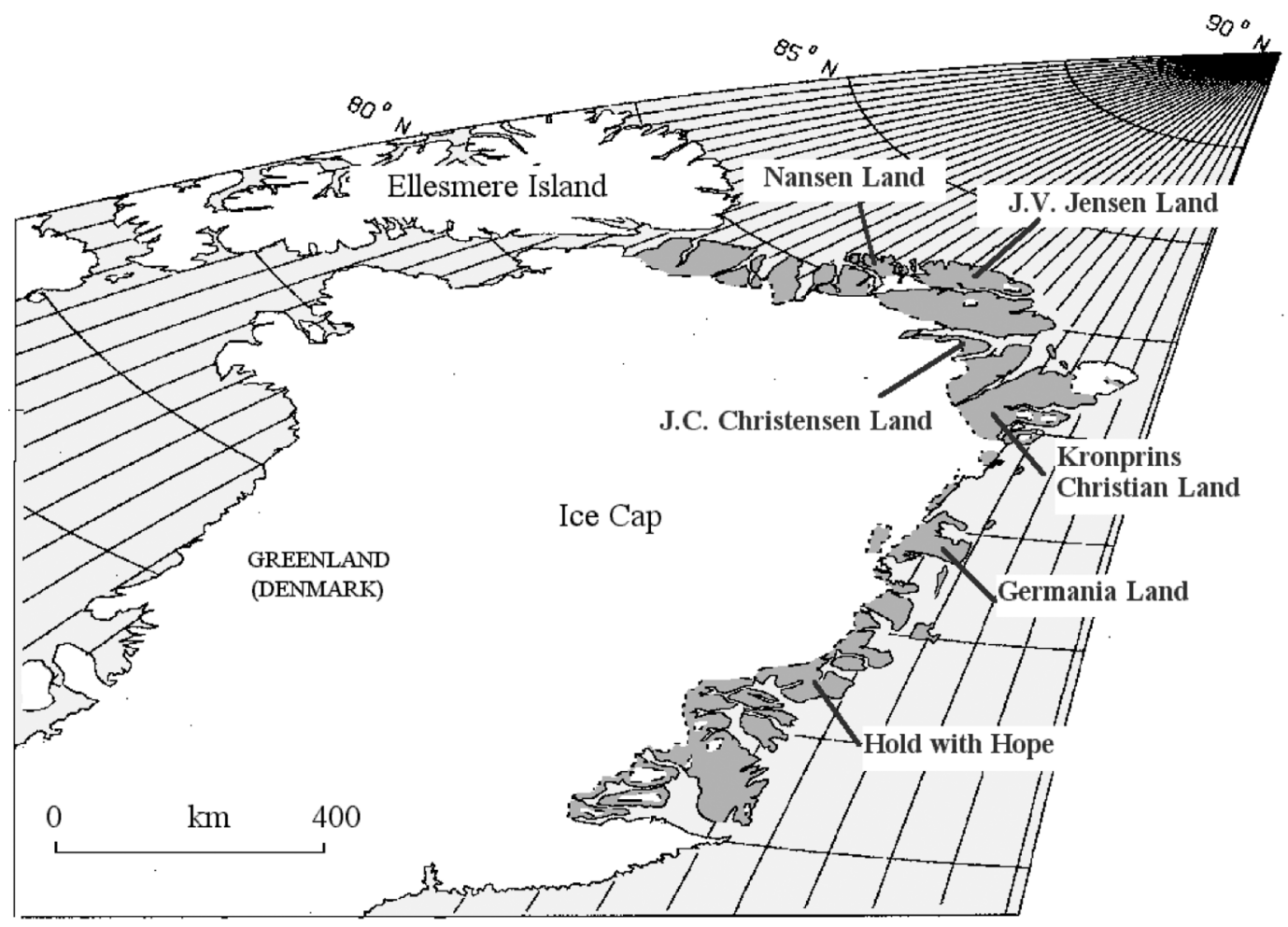

Figure 1. Wolf range (shaded area) and locations of known Wolf reproduction in Greenland, 1978-1998.

of northeast Greenland were interviewed in person or by mail to provide information about number of pups and adults observed, time, place, additional witnesses, and any documentation (photo, video). Third, all 62 field reports by expeditions during the same period were reviewed. Fourth, literature review. Not all reports of sightings were considered sufficiently reliable, especially those referring to tracks of adult Wolves accompanied by Wolf pups. All sightings and unpublished sources were detailed in Marquard-Petersen (2007*).

\section{Mortality}

Data on Wolf mortality were collected from knowledgeable individuals at military bases, the weather station Danmarkshavn, in Ittoqqortoormiit, and through food items in Wolf scats for a related study (MarquardPetersen 1998). The Danish Military served as the police authority in the national park, and their recently declassified archives were searched to acquire police reports on the killing of Wolves other than through legal harvest.

\section{Statistical Analysis}

Single-factor analysis of variance (ANOVA) was used to test for statistically significant differences be- tween mean litter sizes in Greenland, on the Canadian Arctic Archipelago, and in the rest of North America $\left(\mathrm{H}_{0}\right.$ : All means were equal). Because the sample size from Greenland was small, I did not rely on an assumption of normality but used normal probability plotting to see if the data resembled the normal shape. I then completed a formal Anderson-Darling test which is valid for sample sizes $\geq 8$ and which provides a conservative estimate in the presence of ties, i.e., level of significance is smaller than nominal level (D'Agostino 1986). An F-test was used to check the ANOVA assumption of equal population variances, because sample sizes were small (McPherson 2001). Logarithmic transformation was used to meet the assumptions of parametric statistics. A Tukey multiple comparison post-hoc test with unequal sample sizes was used to determine between which population means differences existed $\left(\mathrm{H}_{0}\right.$ : All means were equal).

I used a one-tailed Mann-Whitney U-test to test whether mean litter size differed significantly between large packs ( $\geq 4$ Wolves) and small packs ( $\leq 3$ Wolves) $\left(\mathrm{H}_{0}\right.$ : Large packs were not having significantly more pups than small packs). I used a nonparametric test, because log and square root transformations failed to 
TABLE 1. Known Wolf productivity in Greenland, 1978-1998

\begin{tabular}{lcccl}
\hline \hline Area & Year & $\begin{array}{c}\text { Adults Seen } \\
\text { (present) }^{1}\end{array}$ & Pups & Reference \\
\hline Hold with Hope & 1988 & 2 & 2 & Turner and Dennis 1989 \\
& 1990 & 2 & 2 & Burton 1990 \\
& 1992 & 6 & 3 & Marquard-Petersen 1994 \\
Germania Land & 1995 & $(5)$ & 1 & Marquard-Petersen 2007* \\
South. Kronprins Chr. L. & 1988 & 4 & 2 & Maagaard 1988 \\
& 1993 & $0(2)$ & 1 & Marquard-Petersen 2007* \\
J.C. Christensen Land & 1994 & 1 & 1 & Marquard-Petersen 2007* \\
J.V. Jensen Land & 1997 & 1 & 1 & Marquard-Petersen 2007* \\
& 1993 & 5 & 3 & Marquard-Petersen 2007* \\
Nansen Land & 1994 & 1 & 3 & Marquard-Petersen 2007* \\
& 1985 & $2(7)$ & 3 & Dawes et al. 1986; Bennike et al. 1989 \\
\hline \multicolumn{5}{l}{} \\
\hline \hline
\end{tabular}

${ }^{1}$ Number of adults actually seen with the pups. Number of adults known to be present given in parentheses.

achieve normality or to stabilize the variances. I assumed that all pups in a single litter came from one female. This assumption seemed reasonable given the low prey density (see Marquard-Petersen 2007*, in press), making it extremely unlikely that multiple females in the same pack had produced pups.

I used linear regression to examine the relationship between pup production and pack size or latitude. Residuals were summed and plotted to detect potential presence of bias in the regression models and to evaluate the need for transformation. Normality was checked using normal probability plots and formal tests, using either the Anderson-Darling test or the ShapiroWilk W statistic depending upon the presence of ties (Shapiro and Wilk 1965; see also Zar 1999; Sahai and Ageel 2000).

Statistical tests were conducted on computer using MINITAB, Release 14 and Microsoft Excel (see Fleming and Nellis 2000; Bernstein and Rowe 2001) supplemented by Analyze-it for Microsoft Excel (Analyze-it Software Ltd.). Statistical significance was at the 0.05 level.

\section{Results}

\section{Reproduction}

During the period 1978 to 1998 , at least 11 litters were produced in six areas. Two areas were located in East Greenland; four were located in North Greenland (Figure 1). Pups were observed by me during one summer only (Marquard-Petersen 1994). Wolves were probably not denning in or near the other areas of fieldwork as evidenced by a low density of fresh tracks. Of the people interviewed, nine provided information on sightings of Wolf pups or dens. The literature review identified five published records of Wolf litters in Greenland and six unpublished records. Overall mean litter size was $2.0 \mathrm{pups} /$ litter $(\mathrm{SD}=0.9)$. Mean litter size of Wolves in North Greenland did not differ from that of Wolves in East Greenland (Table 1). Known pup production in Greenland was highest during the period 1992-1994. There was a very strong positive correlation between Greenland Wolf pack size and pup production $(\mathrm{r}=0.91 ; P=0.0001)$. The difference in pup production between large and small packs was statistically significant (Mann-Whitney $U=1.0, n=11$, $P=0.004$ ). Details on pup sightings and den sites in individual areas are given in Marquard-Petersen $(2007 *)$. One-way ANOVA and Tukey tests on mean litter sizes suggested that Wolves in northeast Greenland have significantly $\left(\mathrm{F}_{[2,225]}=11.13, P<0.0001\right)$ fewer pups than: (a) Wolves on the Canadian Arctic Archipelago $($ mean $=4.2$ pups/litter, $q=4.91, \mathrm{df}=225)$ and (b) the contiguous parts of North America (mean $=5.1$ pups/litter, $q=7.38$, df $=225$ ). Average litter size in Greenland was the lowest reported for Wolves during summer using similar methods (Table 2).

\section{Mortality}

Eight mortalities were identified and were predominantly caused by humans (Table 3 ). No signs of disease were reported. Three Wolves were shot in separate incidents after conflicts with tethered sled dogs. Two of these were males; one was killed by the military and one by personnel at Danmarkshavn weather station. Both killings occurred after the Wolves repeatedly had been fighting with tethered dogs. One female Wolf was killed accidentally when shot with bird pellets as a deterrence after frequenting Danmarkshavn for an extended period. This female mated with sled dogs (Maagaard and Graugaard 1994), and eventually became a nuisance to station personnel. Of the remaining five mortalities, two Wolves were harvested legally by Inuit hunters in Jameson Land, one was killed by ecotourists who apparently misinterpreted inquisitive behavior for aggression, and two died from unknown causes. Remains of one of these Wolves were found 
TABLE 2. Average litter sizes reported for Wolves in North America as determined by sightings of pups during summer (May-September)

\begin{tabular}{|c|c|c|c|c|c|}
\hline \multirow[b]{2}{*}{ Location } & \multicolumn{3}{|c|}{ Litter Size } & \multirow[b]{2}{*}{ Range } & \multirow[b]{2}{*}{ Reference } \\
\hline & Latitude & $\overline{\mathrm{x}} \pm \mathrm{SD}$ & $\mathrm{n}$ & & \\
\hline Northeast Greenland & $70-83^{\circ} \mathrm{N}$ & $2.0 \pm 0.9$ & 11 & $1-3$ & Present study \\
\hline \multirow{4}{*}{ Ellesmere Island } & $76-82^{\circ} \mathrm{N}$ & 3.0 & 1 & - & Grace 1976 \\
\hline & & $3.3 \pm 1.8$ & 8 & $1-6$ & Mech 1995 \\
\hline & & 5 & 1 & - & Marquard-Petersen $2007^{*}$ \\
\hline & & 5 & 1 & - & Marquard-Petersen $2007^{*}$ \\
\hline \multirow[t]{5}{*}{ SW Queen Elizabeth Islands } & $74-78^{\circ} \mathrm{N}$ & $4.0 \pm 3.3$ & 6 & $1-10$ & Miller and Russell 1977 \\
\hline & & 3 & 1 & - & Miller 1998* \\
\hline & & $3.6 \pm 1.1$ & 5 & $2-5$ & Gray 1993 \\
\hline & & 1 & 1 & - & Marquard-Petersen $2007^{*}$ \\
\hline & & 3 & 1 & - & Marquard-Petersen $2007 *$ \\
\hline \multirow[t]{2}{*}{ Banks Island } & $71-74^{\circ} \mathrm{N}$ & 4 & 1 & - & Marquard-Petersen $2007^{*}$ \\
\hline & & 6 & 1 & - & Marquard-Petersen $2007 *$ \\
\hline Central Baffin Island & $69^{\circ} \mathrm{N}$ & $4.7 \pm 1.0$ & 6 & $3-6$ & Clark $1971 *$ \\
\hline \multirow[t]{2}{*}{ Northern Alaska } & $68^{\circ} \mathrm{N}$ & $5.3 \pm 1.5$ & 3 & $4-7$ & Chapman 1977* \\
\hline & & 2 & 1 & - & Haugen $1987 *$ \\
\hline \multirow[t]{3}{*}{ Northern mainland Canada } & $65^{\circ} \mathrm{N}$ & $3.5 \pm 0.7$ & 2 & $3-4$ & Kelsall 1960 \\
\hline & & $3.5 \pm 1.6$ & 11 & $1-6$ & Kuyt 1972 \\
\hline & & $5.5 \pm 0.5$ & 2 & $5-6$ & Williams $1990 *$ \\
\hline \multirow{3}{*}{ Denali Park, Alaska } & $64^{\circ} \mathrm{N}$ & $5.2 \pm 1.1$ & 5 & $4-6$ & Murie 1944 \\
\hline & & 3.0 & 1 & - & Chapman 1977* \\
\hline & & $5.9 \pm 1.8$ & 7 & $4-9$ & Haber $1977^{*}$ \\
\hline \multirow[t]{2}{*}{ South-central Alaska } & $63^{\circ} \mathrm{N}$ & $3.8 \pm 2.8$ & 73 & $1-9$ & Mech et al. 1998 \\
\hline & & $5.8 \pm 1.0$ & 28 & $2-9$ & Ballard et al. 1987 \\
\hline \multirow[t]{2}{*}{ Northern Alberta } & $58^{\circ} \mathrm{N}$ & $4.4 \pm 1.1$ & 5 & $3-6$ & Carbyn $1975^{*}$ \\
\hline & & $5.0 \pm 1.6$ & 5 & $3-7$ & Fuller and Keith $1980^{1}$ \\
\hline Montana/British Columbia & $50^{\circ} \mathrm{N}$ & $6.0 \pm 0.8$ & 8 & $5-7$ & Ream et al. 1991 \\
\hline \multirow[t]{3}{*}{ Northern Minnesota } & $49^{\circ} \mathrm{N}$ & $6.4 \pm .1 .6$ & 8 & $4-9$ & Stenlund $1955^{*}$ \\
\hline & & $3.2 \pm 1.4$ & 13 & $2-6$ & Mech $1977^{2}$ \\
\hline & & $4.9 \pm 1.4$ & 15 & $3-7$ & Fritts and Mech 1981 \\
\hline Isle Royale, Michigan & $48^{\circ} \mathrm{N}$ & 7.0 & 1 & - & Peterson 1977 \\
\hline Southeastern Ontario & $46^{\circ} \mathrm{N}$ & $6.4 \pm 1.6$ & 8 & $4-9$ & Pimlott et al. $1969^{*}$ \\
\hline
\end{tabular}

${ }^{1}$ Using minimum estimates from the authors' Table 2.

${ }^{2}$ Declining prey population (Van Ballenberghe and Mech 1975)

in a Wolf scat (Marquard-Petersen 1998). The skeletal remains of the other Wolf were found by a military sled patrol in March 1993 at Krumme Langs $\varnothing$, O. Rømer Land. I examined the skull of this animal at Daneborg in July 1993. It showed what appeared to be a foreshortening of the rostrum that had caused the lower canines to wear furrows into the proximal side of the upper canines. Unlike workers in some other areas on North America (Carbyn 1975*; Pletscher et al. 1997; Peterson et al. 1998), no Wolf carcasses were found during the field work .

\section{Discussion}

\section{Reliability of Data}

Were these primarily incidental, non-systematic sightings in summer reliable indicators of productivity of Wolves in Greenland? There was some evidence from other areas to suggest that they were. Ten years of field research on a Wolf pack on Ellesmere Island showed that early pup survival was high (100\%) and constant, because all pups that emerged from the den were still alive when the investigator left the study area in August of each year (Mech 1995). On central Baffin Island, during the summers of 1965-1969, known pup survival until three or four months of age was $89 \%$, and mortality was limited to a single incident where three pups presumably drowned during a river crossing (Clark 1971*). In Alaska, average pup survival during summer was at least 91\% in Denali Park (Mech et al. 1998) and perhaps up to $97 \%$ in the Nelchina Basin during the first six months of life (Ballard et al. 1987). On the Kenai Peninsula, Alaska, pup survival was $80 \%$ between May and October (Peterson et al. 1984). On the Alexander Archipelago, southeast Alaska, high survivorship of pups was noted during three summers (Person 2001*). Taken together, these studies suggest that the Greenland data fairly accurately reflect the number of pups that emerged from the den.

Other factors supported accuracy of the data. In all but two cases, one or more adult Wolves were seen with the pups. Litters of Wolf pups typically play and travel with adults as a group until about eight weeks 
TABLE 3. Summary of mortality data from eight Wolves known to have died in northeast Greenland, 1985-1998.

\begin{tabular}{llcccl}
\hline \hline $\begin{array}{l}\text { Date of } \\
\text { Death }\end{array}$ & \multicolumn{1}{c}{ Location } & Sex & $\begin{array}{c}\text { Estimated } \\
\text { Age }\end{array}$ & $\begin{array}{c}\text { Cause of } \\
\text { Death }\end{array}$ & Comments \\
\hline 27 June 1985 & Germania Land: Danmarkshavn & $\mathrm{M}$ & Unknown $^{1}$ & Shot & Killed after conflicts with sled dogs. \\
26 August 1988 & Hold with Hope: Badlanddalen & $\mathrm{F}$ & $7-10$ years & Shot & Killed by ecotourists. \\
September 1992 & Jameson Land: Nordøstbugt & $\mathrm{M}$ & $1-3$ years & Shot & Killed by Inuit hunter. \\
-/-/1993 & O. Rømer Land: Krumme Langs & $?$ & $1-3$ years & Unknown & Carcass found by military patrol. \\
-/-/1993 & Germania Land: Danmarkshavn & $\mathrm{F}$ & Unknown $^{1}$ & Shot & Killed accidentally (shotgun blast). \\
-/-/1995 & Peary Land: Frigg Fjord & - & Unknown $^{1}$ & Unknown & Wolf remains found in a wolf scat. \\
19 April 1996 & Kronprins Chris. Land: Sta. Nord & $\mathrm{M}$ & Unknown $^{1}$ & Shot & Killed after conflicts with sled dogs. \\
January 1998 & Jameson Land: Constable Point & $\mathrm{M}$ & Unknown $^{1}$ & Shot & Killed by Inuit hunters. \\
\hline
\end{tabular}

${ }^{1}$ Carcass was destroyed and unavailable for inspection.

${ }^{2}$ Age estimated based upon tooth wear.

${ }^{3}$ Age estimated based upon tooth wear. Teeth showed no signs of normal wear.

of age when they start making short trips alone (Packard et al. 1992), increasing the likelihood that all pups were present. The frequent involvement of helicopters allowed observers to hover or move in for a closer look. An accurate count was facilitated by treeless terrain. These facts support the data, making it less likely that additional pups were overlooked. Sample size was small, but was comparable to that reported in other studies of Wolves in the High Arctic (Mech 1995: $\mathrm{n}=8$; Miller and Reintjes 1995: $n=11$ ). It was noteworthy that it took 21 years to accumulate the 11 sightings analyzed here. Thus, procuring a large sample size of 30 in this extraordinarily remote region could take as long as the year 2030 at the present level of human activity and known frequency of reproduction. Other authors conducting fieldwork involving Wolf pups in the High Arctic have noted similar difficulties in their data collection (Packard et al. 1992). Nonetheless, litter sizes should be considered minimum pup production, as some pups could have died soon after birth. Observations of presumably complete Wolf litters in summer have also been reported by others (Fritts and Mech 1981; Ballard et al. 1987; Fuller 1989; Ream et al. 1991) and during studies of other canids; e.g. African wild dogs (Lycaon pictus, Creel et al. 2004). Total counts are rarely possible (Van Ballenberghe et al. 1975).

\section{Litter Sizes}

Lower mean litter sizes have been reported by others, but calculations included packs that produced no pups (Mech 1977; Fritts and Mech 1981). Average litter size is a useful index of population productivity that is a function of the proportion of Wolves that breed, in turn a function of age structure, pack size, and number of packs relative to lone Wolves (Fuller 1989). Age structure may influence productivity, because most wild female Wolves do not breed until two or three years of age, and many probably not until four or five years of age (Mech 1991). Pack size determines number of females and helpers in a pack and has been correlated with productivity (Harrington et al. 1983).
Maximum observed litter size during the 21 years suggested that productivity of Wolves in Greenland under optimal conditions was limited to three pups. Mean maximum litter size from 17 studies employing similar methods was $7.1 \mathrm{pups} / \mathrm{litter}$ (Table 2). Thus, available data suggested that mean maximum productivity of Wolves in Greenland was $58 \%$ below that reported by the studies referenced in Table 2 .

Litter size data from packs elsewhere in the High Arctic observed in mid-summer showed that a maximum litter size of 10 pups was observed in the Canadian Arctic Archipelago, although Miller (1978) stated that 11 pups were seen in one litter on southwestern Melville Island. This unusual observation may have represented $>$ one litter similar to four sightings of 11-12 pups, representing two litters in Denali Park, Alaska (Mech et al. 1998). Multiple litters in one Wolf pack have not been reported sighted in Greenland and are likely exceptionally rare, if they occur at all, given the low prey density and small pack sizes.

The most likely reason for low litter sizes in Greenland was related to prey availability and vulnerability. Overall density of Muskox (Ovibos moschatus) in the study region was $5.3 \mathrm{Muskoxen} / 100 \mathrm{~km}^{2}$ assuming a midpoint estimate of 10918 Muskoxen (Boertmann and Forchhammer 1992*; Boertmann et al. 1992). This was extraordinarily low biomass relative to lower latitudes (see Marquard-Petersen in press for comparative analysis), and was noteworthy because Wolves inhabiting regions of low prey density have lower success in reproduction (Messier 1985). For example, a study of 155 Wolves from Alaska concluded that (1) in utero litter sizes declined with declining prey availability per Wolf, (2) more females reproduced when per capita ungulate biomass was moderate to high, and (3) suppression of estrus occurred at very low prey availability (Boertje and Stephenson 1992). Results of a study of productivity of tundra Wolves in the Keewatin District, Northwest Territories, suggested that reproduction was positively correlated with availability of prey (Hillis 1990*). Furthermore, mean productivity in Wolves 


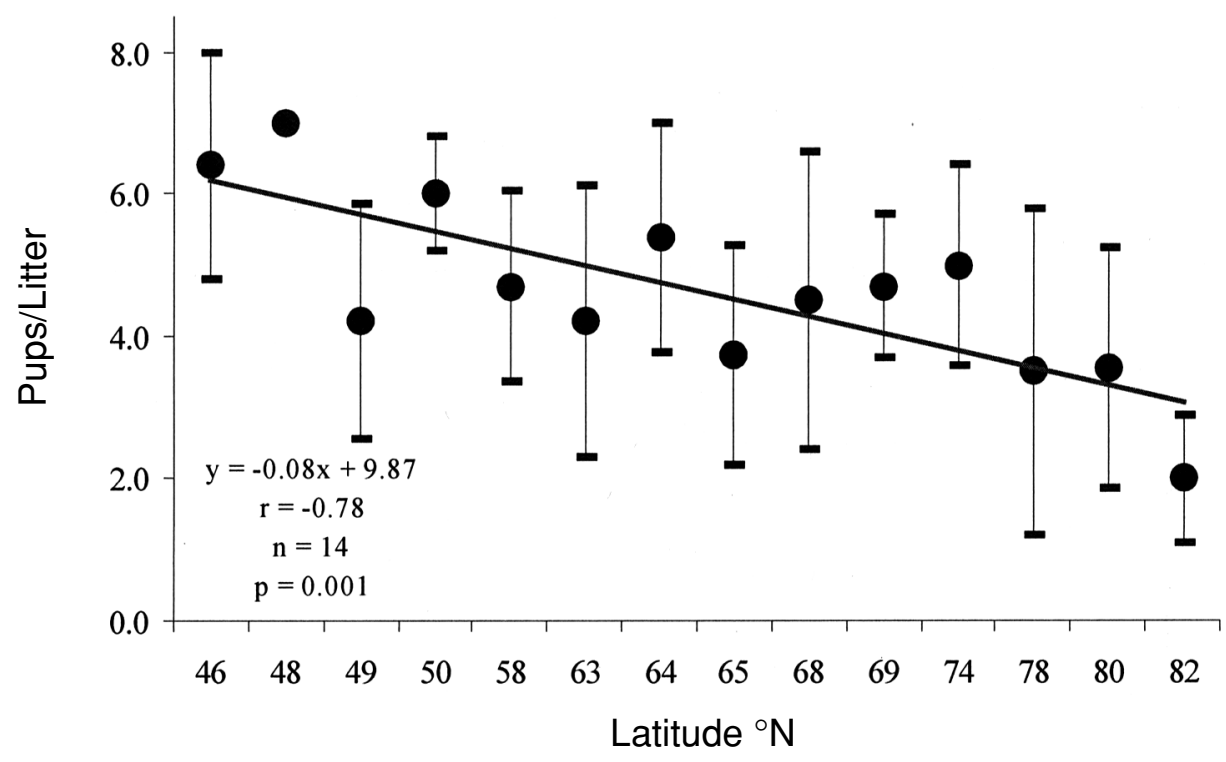

FIGURE 2. Average litter size and standard deviation of Wolves in North America relative to increasing latitude determined by sightings of pups in summer. From references in Table 2.

apparently declines with increasing latitude (Figure 2), perhaps because there are fewer prey species available to Wolves in the High Arctic than in lower latitudes, as the number of species per unit area decreases with increasing latitude (Pagel et al. 1991). Also, large ungulate prey in the High Arctic is scattered over vast areas in a limited and clumped distribution due to complex topography (Tener 1963; Thing et al. 1987; Miller 1993*; Aastrup 2000*). This fact would adversely affect the ability of Wolves to locate their prey. Thus, low food availability offered the most plausible explanation for the small average litter sizes reported here. It was noteworthy that the three sightings of single pups in North Greenland were made in areas known to support the lowest densities of Muskoxen.

Other causes believed to be responsible for small litter sizes in Wolves include diseases, such as canine parvovirus or infectious canine hepatitis (Boyd and Jimenez 1994), and inbreeding depression (Laikre and Ryman 1991). There was no evidence that any of these factors were important in my study region.

Larger packs in Greenland were producing more pups than smaller packs. Surviving litter size has been correlated with pack size (Harrington et al. 1983), although some researchers found no evidence of this relationship (Pletscher et al. 1997). Larger packs kill more ungulate prey than smaller packs but have less food available per pack member than smaller packs (Fritts and Mech 1981; Messier and Crête 1985; Ballard et al. 1987; Messier 1987; Thurber and Peterson 1993; Dale et al. 1995). Pack members (“auxiliaries") help feed the pups in larger packs thereby increasing pup survival (Brainerd et al. 2008). Pack size and litter size in an increasing Wolf population with abundant prey in Minnesota were positively correlated, and litter size in a declining population at low prey density was inversely related to pack size (Harrington et al. 1983). Availability of food influenced ability or willingness of subordinate Wolves to provide food for pups, thus affecting pup survival (Harrington et al. 1983). Both ecological conditions are relevant to the present study, because the Wolf population in Greenland was expanding during the years following its documented reoccurrence (1978) until about 1992 followed by a decline or leveling off during the mid-1990s (Marquard-Petersen $2007 *$ ). More post-1993 sightings of pups were needed to investigate whether the inverse relationship between litter size and pack size observed in Minnesota also occurred in Greenland. Wolf pairs in a declining population in Minnesota produced more surviving pups than larger packs (Harrington et al. 1983). Therefore, Wolf pairs in northeast Greenland that produced fewer pups than larger packs may have experienced higher survival rates, and the smaller litter sizes may represent an adaptation to this extreme environment.

\section{Frequency of Reproduction}

A minimum of 22 pups were produced in the study region between 1985 and 1997. That refuted a claim by Maagaard and Graugaard (1994) that most Greenland Wolves originated from Ellesmere Island and that very few were born in Greenland. Because of paucity of data from the vast study region, firm conclusions 
pertaining to frequency of pup production could not be reached. Nevertheless, some conjecture was possible based upon the Hold with Hope data. Wolves were first sighted in this area in March 1980, but no signs of reproduction were detected until July 1988 (Turner and Dennis 1989) despite expeditions during at least 6 of 10 years, 1978-1987, and a yearly average of 836 linear km (SD $203 \mathrm{~km}$ ) by military sled patrols that patrol the area during winter between January 1980 and June 1988. This did not establish that reproduction did not occur, but simply reflected that no evidence was reported. Pack size during this period apparently never exceeded two Wolves (Marquard-Petersen 2007*). Then, pups were sighted in Hold with Hope in 1988, 1990, 1992, and 1995, and circumstantial evidence suggested reproduction in 1991 (Marquard-Petersen 1994). These facts indicated that Wolves in this particular area produced two or three pups every second or third year during a favorable period from 1988-1992. During other years, 1989, and 1996-1998, it appeared no pups were produced in Hold with Hope as evidenced by absence of fresh diggings at known den sites (cf. Mech 1995) or a low track density. The latter was more revealing than the former, because a single field investigator working in an area only every other year can seldom be certain that all dens were detected. There were no indications that pups were produced in other years or in nearby areas, including Hudson Land and Gauss Peninsula, or that denning conditions (soil, prey availability) were as favorable there.

If an argument is made that these observations were valid for the study region at large and over larger time periods, then pup production appeared to be irregular even under the most favorable circumstances, because Hold with Hope supported the second-largest Muskox population in East Greenland (Boertmann and Forchhammer $1992 *)$. This ungulate availability was supplemented by thousands of geese in summer (Marquard-Petersen 1998). The area was also home to the largest known, contemporary pack size in Greenland of nine Wolves. Frequency of reproduction was almost certainly lower in more marginal areas, such as Germania Land and southern Kronprins Christian Land. If reproduction were irregular, it would support what was known about pup production on the Canadian Arctic Islands where some years were characterized by an absence of pups (Miller and Reintjes 1995). For example, on the western and central Queen Elizabeth Islands, pups were seen in only one of seven surveys (Miller $\left.1993^{*}\right)$. No causal relationship has been established, but Mech (2005) produced data from Ellesmere Island indicating that a six-year absence of Wolf reproduction in one area was the consequence of a decline in Muskoxen and Arctic Hares (Lepus arcticus) due to two snowy summers in four years.

A long reproductive interval and low rate of production of offspring have been reported in other species of arctic mammals, e.g., Polar Bears (Ursus maritimus) in the Beaufort Sea (Amstrup 1995*). Muskox in northeast Greenland probably produce one calf every 2-3 years (Aastrup et al. 1986*; Thing et al. 1987). Adamczewski et al. (1997) noted that “....annual calving [in muskoxen] occurs only under very good conditions in the wild..." Such low reproductive rates are likely a consequence of low availability of forage, because there is a general trend of decreasing productivity with increasing latitude (Crête and Manseau 1996). For example, Tener (1965) stated that Muskox range near Lake Hazen, northern Ellesmere Island, produced 1/3 to $1 / 14$ of forage produced on herbivore range in Jasper and Banff National Parks to the south and on the prairie ranges. The frequency of pup production among Wolves and other canids in lower latitudes is generally much higher. Wolves typically have one litter per pack annually (see Peterson et al. 1984; Ballard et al. 1987; Bjorge and Gunson 1989; Mech 1991; Mech et al. 1998).

\section{Mortality}

Without radiotelemetry, it is very difficult to evaluate the predominant causes of deaths in extant Wolf populations (Carbyn 1975*). Accordingly, numerous researchers in more accessible areas have reported small sample sizes that made definitive conclusions difficult (Mech 1977 ( $n=24)$; Ream et al. $1991(n=12)$; Licht and Fritts $1994(n=10)$; Anthony $1997(n=24)$; Wabakken et al. $2001(n=26)$; Kamler et al. 2003 $(n=12))$. Such limited information should not be disregarded, because sample sizes as small as 10 can give results useful for characterization of populations (Hayek and Buzas 1997). In fact, "in many, if not most, field surveys a small amount of data is all that can be obtained" (Hayek and Buzas 1997, also noted as a problem by Ballard et al. 1997; Creel 1997; Morrison et al. 1998).

My study undoubtedly identified only a fraction of the Wolves that died in the study region during the 21 years. Similar difficulties have been reported by other researchers; e.g., Peterson et al. (1998) who noted that $>90 \%$ of Wolf mortality in their area could not be explained. Nevertheless, it was noteworthy that four of the eight Wolves known to have died were killed by humans inside the Northeast Greenland National Park, where Wolves were legally protected year-round. Events leading up to three of these killings followed a typical pattern. Firstly, people coaxed the particular Wolf or its mate to come closer for photo opportunities by offering them food scraps. Secondly, eventually three of the four Wolves became accustomed to frequenting station areas for extended periods. Wolves then became bolder and began engaging in behavior considered a nuisance by station personnel (e.g., fighting with tethered sled dogs, stealing food from dogs, howling at night keeping personnel awake, scavenging on refuse, raiding the nests of waterfowl nesting on the station area, etc.). Similar nuisance behaviors by Wolves related to garbage and domestic dogs were reported from Ellesmere Island (Grace 1976; Miller 1978; Gray 
1995*). Thirdly, as the perception of a Wolf changed from a valued photo opportunity to a nuisance, efforts were made to chase it away, typically by shooting aerial flares at it. These efforts were universally fruitless, as Wolves quickly learned that such events were harmless. Finally, shots were fired directly at the animal. Three of four Wolves killed by humans inside the national park were shot after conflicts with domestic dogs, demonstrating that the presence of sled dogs in northeast Greenland created an environment with an increased potential for conflicts that in some cases were deleterious to Wolves.

It was unknown how much such killings contributed to overall mortality, because sample size was low, and the data were biased towards inflation of the proportion of human-caused deaths. Such mortality was probably not important at the regional population level, but could be important locally in areas where litter sizes consisted of a single pup, or during times when the population was declining and pup survival was low. Furthermore, the loss of relatively few adult females could have a disproportionately large, adverse effect upon population size in local areas as well as regionally, if the loss occurred in a core Wolf area. Feeding of wildlife in the national park in northeast Greenland was illegal, but was practiced and enforcement was non-existent. No charges were brought to bear against individuals who killed Wolves illegally inside the national park (i.e., not in self-defense). Such killings were generally kept quiet, and details were not readily forthcoming.

In areas outside the High Arctic, the major cause of mortality of species inhabiting protected areas is conflict with people in border areas that become population sinks (Woodroffe and Ginsberg 1998). Four of six Wolves killed by humans in my study region were shot on base areas, suggesting that military or civilian stations constituted periodic population sinks. Although such killings were rare, weather stations, airports, military bases, and field camps may have a measurable, cumulative adverse effect on the small, disjunct Wolf population in the region. Given the apparent extraordinarily low density of Wolves in northeast Greenland (Marquard-Petersen in press), even the occasional killing of one or two Wolves by humans could have a substantial adverse effect by wiping out a disproportionately high percentage of a local population; e.g., in an area occupied by a single Wolf pair. This adverse effect would be exacerbated by the fact that such mortality not necessarily would be counteracted by recruitment from nearby packs given the likely low reproductive rate, insular characteristics of Wolf distribution, and likely low immigration rates into some areas (see Marquard-Petersen in press).

Data were biased, because Wolves killed by humans were more likely to be reported than Wolves that died of natural causes. Thus, mortality from sources known to be important in other populations was poorly represented; e.g., intraspecific strife and malnutrition. In northeastern Minnesota, intraspecific strife was the primary cause of mortality of adult Wolves (Mech 1977). In Denali Park, Alaska, 39\% of known mortality was conspecific (Mech et al. 1998). In central East Greenland, a young sled dog that had become separated from other sled dogs in November 1998 was attacked and killed by a pack of four Wolves, suggesting that intraspecific strife may be equally important in this population. Packs elsewhere often chase and occasionally kill lone Wolves found trespassing in their territory (Peterson et al. 1998). Mortality from malnutrition may be common in my study region, because: (1) some Wolves probably inhabit areas of low relative prey density, (2) the proportion of loners was high (MarquardPetersen in press), and (3) it may be difficult for lone Wolves to kill Muskoxen (cf. Gray 1970; Miller and Gunn 1977). Wolves in a low prey area in Quebec suffered higher mortality from starvation and intraspecific aggression than Wolves in a high-prey area (Messier 1985). There were few comparable data from the High Arctic. Inuit on the Canadian Arctic Archipelago represented the greatest cause of Wolf mortality in that region with some cases of entire packs being wiped out (Miller 1993*).

\section{Acknowledgments}

I am grateful to the $>100$ people who responded to my survey on Wolf productivity in Greenland, to Frank Miller, Canadian Wildlife Service, who shared survey material on Wolves on the Canadian Arctic Islands, and to two anonymous reviewers who provided comments that improved the manuscript.

Documents Cited (marked $*$ in text)

Aastrup, P. 2000. Muskox population studies in Greenland. $\mathrm{Ph} . \mathrm{D}$. thesis, National Environmental Research Institute, Denmark. 279 pages.

Aastrup, P., C. Bay, and B. Christensen. 1986. Biologiske miljøundersøgelser i Nordgrønland, 1984-85. Copenhagen: Greenland Environmental Research Institute. 113 pages. [In Danish with English summary].

Amstrup, S. C. 1995. Movements, distribution, and population dynamics of polar bears in the Beaufort Sea. Unpublished Ph.D. thesis, University of Alaska Fairbanks. 299 pages.

Boertmann, D., and M. Forchhammer. 1992. A review of muskox observations from north and northeast Greenland. Greenland Environmental Research Institute. 36 pages.

Carbyn, L. N. 1975. Wolf predation and behavioural interactions with elk and other ungulates in an area of high prey diversity. Ph.D. thesis, University of Toronto. 233 pages.

Chapman, R. C. 1977. The effects of human disturbance on wolves (Canis lupus L.). M.S. thesis, University of Alaska Fairbanks. 209 pages.

Clark, K. R. F. 1971. Food habits and behavior of the tundra wolf on central Baffin Island. Ph.D. dissertation, University of Toronto. 233 pages.

Gray, D. R. 1995. The wolves of Alert. Final report for Ellesmere Island National Park Reserve, Parks Canada, Department of Canadian Heritage. Greyhound Information Services, Metcalfe, Ontario. 30 pages. 
Haber, G. C. 1977. Socio-ecological dynamics of wolves and prey in a subarctic ecosystem. Ph.D. thesis, University of British Columbia. 786 pages.

Haugen, S. H. 1987. Den-site behavior, summer diet and skull injuries of wolves in Alaska. M.S. thesis, University of Alaska Fairbanks. 205 pages.

Hillis, T. L. 1990. The demography and ecology of the tundra wolf, Canis lupus, in the Keewatin District, Northwest Territories. MS thesis, Laurentian University, Sudbury, Ontario. 203 pages.

Marquard-Petersen, U. 2007. Ecology of the high arctic wolf in northeast Greenland, 1899-1998. Unpublished Ph.D. thesis. University of Copenhagen, Denmark. 389 pages.

Miller, F. L. 1993. Status of wolves in the Canadian Arctic Archipelago. Technical Report series number 173. Canadian Wildlife Service western and northern region. Alberta. 63 pages.

Miller, F. L. 1998. Status of peary caribou and muskox populations within the Bathurst Island complex, south-central Queen Elizabeth Islands, Northwest Territories, July 1996. Technical Report series (317). Canadian Wildlife Service, Prairie \& Northern Region, Edmonton, Alberta. 147 pages.

Person, D. K. 2001. Alexander Archipelago wolves: Ecology and population viability in a disturbed, insular landscape. Ph.D. dissertation, University of Alaska Fairbanks. 174 pages.

Pimlott, D. H., J.A. Shannon, and G.B. Kolenosky. 1969. The ecology of the timber wolf in Algonquin Provincial Park. Ontario Department of Lands and Forests Research Report (Wildlife) (87). 92 pages.

Stenlund, M. H. 1955. A field study of the timber wolf (Canis lupus) on the Superior National Forest, Minnesota. Minnesota Department of Conservation Technical Bulletin (4). 55 pages.

Williams, T. M. 1990. Summer diet and behaviour of wolves denning on barren-ground caribou range in the Northwest Territories, Canada. M.S. thesis, University of Alberta Edmonton. 75 pages.

\section{Literature Cited}

Adamczewski, J. Z., P. F. Flood, and A. Gunn. 1997. Seasonal patterns in body composition and reproduction of female muskoxen (Ovibos moschatus). Journal of Zoology (London) 241: 245-269.

Anthony, R. M. 1997. Home ranges and movements of arctic fox (Alopex lagopus) in Western Alaska. Arctic 50: 147157.

Ballard, W. B., L. A. Ayres, P. R. Krausman, D. J. Reed, and S. G. Fancy. 1997. Ecology of wolves in relation to a migratory caribou herd in northwest Alaska. Wildlife Monographs 135:1-47.

Ballard, W. B., J. S. Whitman, and C. L. Gardner. 1987. Ecology of an exploited wolf population in south-central Alaska. Wildlife Monographs 98: 1-54.

Bennike, O., A. K. Higgins, and M. Kelly. 1989. Mammals of central North Greenland. Polar Record 25(152): 43-49.

Bernstein, I. H., and N. A. Rowe. 2001. Statistical data analysis using your personal computer. Sage Publications: Thousand Oaks, California. 446 pages.

Bjorge, R. R., and J. R. Gunson. 1989. Wolf, Canis lupus, population characteristics and prey relationships near Simonette River, Alberta. Canadian Field-Naturalist 103: 327-334.
Boertje, R. D., and R. O. Stephenson. 1992. Effects of ungulate availability on wolf reproductive potential in Alaska. Canadian Journal of Zoology 70: 2441-2443.

Boertmann, D., M. Forchhammer, C. R. Olesen, P. Aastrup, and H. Thing. 1992. The Greenland muskox population status 1990. Rangifer 12: 5-12.

Boyd, D. K., and M. D. Jimenez. 1994. Successful rearing of young by wild wolves without mates. Journal of Mammalogy 75: 14-17.

Brainerd, S. M., H. Andrén, E. E. Banks, E. H. Bradley, J. A. Fontaine, W. Hall, Y. Iliopoulos, M. D. Jiminez, E. A. Jozwiak, O. Liberg, C. M. Mack, T. H. Meier, C. C. Niemeyer, H. C. Pedersen, H. Sand, R. N. Schultz, D. W. Smith, P. Wabakken, and A. P. Wydeven. 2008. The effects of breeder loss on wolves. Journal of Wildlife Management 72: 89-98.

Burton, R. 1990. Wolves breeding in northeast Greenland. Polar Record 26(159): 334

Creel, S. 1997. Cooperative hunting and group size: Assumptions and currencies. Animal Behaviour 54: 1319-1324.

Creel, S., M. G. L. Mills, and J. W. McNutt. 2004. Demography and population dynamics of African wild dogs in three critical populations. Pages 337-350 in Biology and conservation of wild canids. Edited by D. W. Macdonald and C. Sillero-Zubiri. Oxford University Press, Oxford. 450 pages.

Crête, M., and M. Manseau. 1996. Natural regulation of cervidae along a $1000 \mathrm{~km}$ latitudinal gradient: change in trophic dominance. Evolutionary Ecology 10: 51-62.

D'Agostino, R. B. 1986. Tests for the normal distribution. Pages 367-419 in Goodness-of-fit techniques. Edited by R. B. D'Agostino and M. A. Stephens. Marcel Dekker, New York. 560 pages.

Dale, B. W., L. G. Adams, and R. T. Bowyer. 1995. Winter wolf predation in a multiple ungulate prey system, Gates of the Arctic National Park, Alaska. Pages 223-230 in Ecology and conservation of wolves in a changing world. Edited by L. N. Carbyn, S. H. Fritts, and D. R. Seip. Occasional publication series (35). Canadian Circumpolar Institute. 620 pages.

Dawes, P. R., M. Elander, and M. Ericson. 1986. The wolf (Canis lupus) in Greenland: A historic review and present status. Arctic 39: 119-132.

Fleming, M. C., and J. G. Nellis. 2000. Principles of applied statistics: An integrated approach using Minitab and Excel. Thomson Learning, London. 474 pages.

Fritts, S. H., and L. D. Mech. 1981. Dynamics, movements, and feeding ecology of a newly protected wolf population in northwestern Minnesota. Wildlife Monographs (80). 79 pages.

Fuller, T. K. 1989. Population dynamics of wolves in northcentral Minnesota. Wildlife Monographs (105): 1-41.

Fuller, T. K., and L. B. Keith. 1980. Wolf population dynamics and prey relationships in northeastern Alberta. Journal of Wildlife Management 44: 583-602.

Grace, E. S. 1976. Interactions between men and wolves at an arctic outpost on Ellesmere Island. Canadian FieldNaturalist 90: 149-156.

Gray, D. R. 1970. The killing of a bull muskox by a single wolf. Arctic 23: 197-199.

Gray, D. R. 1983. Interactions between wolves and muskoxen on Bathurst Island, N.W.T., Canada. Acta Zoologica Fennica 174: 255-257 
Gray, D. R. 1993. The use of muskox kill sites as temporary rendezvous sites by arctic wolves with pups in early winter. Arctic 46: 324-330.

Harrington, F. H., L. D. Mech, and S. H. Fritts. 1983. Pack size and wolf pup survival: Their relationship under varying ecological conditions. Behavioral Ecology and Sociobiology 19: 19-26.

Hayek, L-A. C., and M. A. Buzas. 1997. Surveying natural populations. Columbia University Press, New York. 563 pages.

Kamler, J. F., W. B Ballard, E. B. Fish, P. R. Lemons, K. Mote, and C. C. Perchellet. 2003. Habitat use, home ranges, and survival of swift foxes in a fragmented landscape: conservation implications. Journal of Mammalogy 84: 989-995.

Kelsall, J. P. 1960. Co-operative studies of barren-ground caribou, 1957-58. Canadian Wildlife Service, Wildlife Management Bulletin (15).

Kuyt, E. 1972. Food habits of wolves on barren-ground caribou range. Canadian Wildlife Service Report Series (21). 36 pages.

Laikre, L., and N. Ryman. 1991. Inbreeding depression in a captive wolf (Canis lupus) population. Conservation Biology $5: 33-40$.

Licht, D. S., and S. H. Fritts. 1994. Gray wolf (Canis lupus) occurrences in the Dakotas. The American Midland Naturalist 132: 74-81.

Maagaard, L. 1988. Ynglefund af polarulv (Canis lupus arctos) ved Danmarkshavn Nordøstgrønland. Flora og Fauna 94: 89-92. [In Danish with English summary].

Maagaard, L., and J. Graugaard. 1994. Female high arctic wolf, Canis lupus arctos, mating with domestic dogs, Canis familiaris, in northeast Greenland. Canadian FieldNaturalist 108: 374-375.

Marquard-Petersen, U. 1994. Dens and summer pack size of arctic wolves in Hold with Hope, East Greenland. Polar Record 30(172): 46-49.

Marquard-Petersen, U. 1998. Food habits of arctic wolves in Greenland. Journal of Mammalogy 79: 236-244.

Marquard-Petersen, U. In press. Abundance, social organization and population trend in the arctic wolf in north and east Greenland, 1978-1998. Canadian Journal of Zoology.

McPherson, G. 2001. Applying and interpreting statistics: A comprehensive guide. Springer, New York. 640 pages.

Mech, L. D. 1977. Productivity, mortality, and population trends of wolves in northeastern Minnesota. Journal of Mammalogy 58: 559-574

Mech, L. D. 1991. The way of the wolf. Voyageur Press, Stillwater, Minnesota. 120 pages.

Mech, L. D. 1995. A ten-year history of the demography and productivity of an high arctic wolf pack. Arctic 48: 329-332.

Mech, L. D. 2005. Decline and recovery of a high arctic wolfprey system. Arctic 58: 305-307.

Mech, L. D., L. G. Adams, T. J. Meier, J. W. Burch, and B. W. Dale. 1998. The wolves of Denali. University of Minnesota Press, Minneapolis. 227 pages.

Messier, F. 1985. Social organization, spatial distribution, and population density of wolves in relation to moose density. Canadian Journal of Zoology 63: 1068-1077.

Messier, F. 1987. Physical condition and blood physiology of wolves in relation to moose density. Canadian Journal of Zoology 65: 91-95.

Messier, F., and M. Crête. 1985. Moose-wolf dynamics and the natural regulation of moose populations. Oecologia (Berlin) 65: 503-512.
Miller, F. L. 1978. Interactions between men, dogs and wolves on western Queen Elizabeth Islands, Northwest Territories, Canada. The Musk-ox 22: 70-72.

Miller, F. L., and A. Gunn. 1977. Group of muskoxen attacked by a solitary high arctic wolf, Prince of Wales Island, Northwest Territories. The Musk-ox 20: 87-88.

Miller, F. L., and F. D. Reintjes. 1995. Wolf-sightings on the Canadian arctic islands. Arctic 48: 313-323.

Miller, F. L., and R. H. Russell. 1977. Unreliability of strip aerial surveys for estimating numbers of wolves on western Queen Elizabeth Islands, Northwest Territories. Canadian Field-Naturalist 91: 77-81.

Morrison, M. L., B. G. Marcot, and R. W. Mannan. 1998. Wildlife-habitat relationships. University of Wisconsin Press. Madison, Wisconsin. 435 pages.

Murie, A. 1944. The wolves of Mount McKinley. Fauna of the National Parks of the United States, Fauna Series (5). U.S. Government Printing Office. Washington D.C. 238 pages.

Packard, J. M., L. D. Mech, and R. R. Ream. 1992. Weaning in an high arctic wolf pack: Behavioral mechanisms. Canadian Journal of Zoology 70: 1269-1275.

Pagel, M. D., R. M. May, and A. R. Collie. 1991. Ecological aspects of the geographical distribution and diversity of mammalian species. The American Naturalist 37: 791-815.

Peterson, R. O. 1977. Wolf ecology and prey relationships on Isle Royale. U.S. National Park Service Scientific Monograph Series (11). 210 pages.

Peterson, R. O., J. D. Woolington, and T. N. Bailey. 1984 Wolves of the Kenai Peninsula, Alaska. Wildlife Monographs 88: 1-52.

Peterson, R. O., N. J. Thomas, J. M. Thurber, J. A. Vucetich, and T. A. Waite. 1998. Population limitation and the wolves of Isle Royale. Journal of Mammalogy 79: 828841.

Pletscher, D. H., R. R. Ream, D. K. Boyd, M. W. Fairchild, and K. E. Kunkel. 1997. Population dynamics of a recolonizing wolf population. Journal of Wildlife Management 61: 459-465.

Ream, R. R., M. W. Fairchild, D. K. Boyd, and D. H. Pletscher. 1991. Population dynamics and home range changes in a colonizing wolf population. Pages 349-366 in The greater Yellowstone Ecosystem: Redefining America's wilderness heritage. Yale University Press, New Haven. 428 pages.

Riewe, R. R. 1975. The high arctic wolf in the Jones Sound region of the Canadian High Arctic. Arctic 28: 209-212.

Riewe, R. R. 1977. The utilization of wildlife in the Jones Sound region by the Grise Fiord Inuit. Pages 623-644 in Truelove Lowland, Devon Island, Canada: A high arctic ecosystem. Edited by L. C. Bliss. The University of Alberta Press, Edmonton. 714 pages.

Sahai, H. and M. I. Ageel. 2000. The analysis of variance. Birkhäuser, Boston. 742 pages.

Shapiro, S. S. and M. B. Wilk. 1965. An analysis of variance test for normality (complete samples). Biometrika 52: 591611.

Soper, J. D. 1928. A faunal investigation of southern Baffin Island. National Museum of Canada, Bulletin (53), Biological Series (15). F.A. Acland, Printer to the King's Most Excellent Majesty, Ottawa, Ontario. 143 pages.

Tener, J. S. 1963. Queen Elizabeth Islands game survey, 1961. Canadian Wildlife Service, Occasional Paper (4). 50 pages.

Tener, J. S. 1965. Muskoxen in Canada: A biological and taxonomic review. Queen's Printer, Ottawa, Ontario. 166 pages. 
Thing, H., D. R. Klein, K. Jingfors, and S. Holt. 1987. Ecology of muskoxen in Jameson Land, northeast Greenland. Holarctic Ecology 10: 95-103.

Thurber, J. M., and R. O. Peterson. 1993. Effects of population density and pack size on the foraging ecology of gray wolves. Journal of Mammalogy 74: 879-889.

Turner, J. V. N., and R. H. Dennis. 1989. Confirmed breeding of polar wolf in northeast Greenland in 1988. Polar Record 25(155): 353.

Van Ballenberghe, V. and L. D. Mech. 1975. Weight, growth, and survival of timber wolf pups in Minnesota. Journal of Mammalogy 56: 44-63.
Van Ballenberghe, V., A. W. Erickson, and D. Byman. 1975. Ecology of the timber wolf in northeastern Minnesota. Wildlife Monographs 43: 1-43.

Wabakken, P., H. Sand, O. Liberg, and A. Bjärval. 2001. The recovery, distribution, and population dynamics of wolves on the Scandinavian peninsula, 1978-1998. Canadian Journal of Zoology 79: 710-725.

Woodroffe, R., and J. R. Ginsberg. 1998. Edge effects and the extinction of populations inside protected areas. Science 280: 2126-2128.

Zar, J. H. 1999. Biostatistical analysis. Prentice-Hall, Upper Saddle River, New Jersey. 663 pages.

Received 10 December 2007

Accepted 18 February 2009 